\title{
Some key developments in international financial management
}

\author{
Wolfgang Breuer ${ }^{1}\left[\right.$ ] Santiago Ruiz de Vargas ${ }^{2}([)$
}

Published online: 29 June 2021

(C) The Author(s) 2021

\section{International financial management and valuation: an important field of financial research}

International financial management is about investment and financing decisions confronting the management of multinational companies due to the international context of their activities. Investment and financing decisions involve the valuation of uncertain future cash flows (Ross 2004, p. 1). A key element of the international context is that these decisions are affected by exchange rate risk. Therefore, the methodology used to support rational decision making in an international context must capture the additional complexity that exchange rate risk and exchange rate forecasting pose.

Forty years ago, in a special issue of this journal, the areas of research pertinent to international financial management were addressed (Stehle 1981, pp. 75-76) and a status report on the theory of international capital markets was given (Franke 1981, pp. 51-66). After four decades, this special issue presents articles of current interest that address important aspects of the research field of international financial management and valuation. But before presenting these, we would like to offer a brief update on where we stand today in the field of international financial management.

In these 40 years, the number of countries and currencies has increased substantially, to more than 220 countries with more than 150 currencies as of the beginning of this decade. ${ }^{1}$ The world has experienced rapid internationalization and widespread integration of capital markets (e.g. Obstfeld and Taylor 2004; Das 2004, 2006; Frieden 2020). This has caused business and investor cross-border activities to

\footnotetext{
1 Data retrieved from the United Nations website, see United Nations (2021), on January 29, 2021 (access date).
}

Wolfgang Breuer

wolfgang.breuer@bfw.rwth-aachen.de

Santiago Ruiz de Vargas

santiago.ruizdevargas@noerr.com

1 Department of Finance, RWTH Aachen University, Aachen, Germany

2 Advisory Services, NOERR AG WPG StBG, Munich, Germany 
experience enormous expansion. Trading volumes on international capital markets have been boosted considerably, and the array of available financing instruments has substantially increased. The triennial central survey of the Bank of International Settlements reports a daily total OTC foreign exchange turnover of US\$ 6.6 trillion for April 2019 ("net-net" basis, Bank for International Settlements 2019, Table 1, p. 1) in comparison to US\$ 0.6 trillion in April 1989, i.e. three decades earlier (grand total, Bank for International Settlements 1996, p. 3).

The framework for investment and financing decisions in an international context is given by the international monetary system and the integration, depth and breadth of international financial markets. Of course, the growing integration of real goods and services markets and the intensity of international trade also play an important role in international financing and investment decisions. Since the breakdown of the Bretton Woods system of fixed exchange rates 50 years ago, most developed countries have adopted a free float, and a comprehensive liberalization of capital and currentaccount transactions has taken place. This still reflects the current overall trend (see International Monetary Fund (IMF) 2020, p. 3). However, some developed countries in Europe introduced a common currency in 1999, the euro, thus establishing a fixedrate regime for their common market, while accepting a free float of their currency in relation to countries outside this monetary union (Baldwin and Wyplosz 2020; Brasche 2013; Wagener and Eger 2014). Consequently, managing exchange rate risk and forecasting future exchange rates have become essential aspects of international financial management decision making since the breakdown of the Bretton Woods system.

These developments have been accompanied by wide-ranging theoretical and empirical research on international financial management, most of which applies and extends the concepts and methodology that have been developed in financial economics. In particular, a theory of international capital markets establishing equilibrium conditions based on the absence of arbitrage (see e.g. Ross 2004; Kruschwitz and Löffler 2020; Franke and Hax 2009) has been developed (Solnik 1974; Grauer et al. 1976; Mehra 1978; Sercu 1980; Stulz 1981a; Adler and Dumas 1983; Ross and Walsh 1983, among others).

In the next section, we will give a brief overview of the relevance of internationally related topics at the annual meetings of the European Finance Association (EFA). It shows that aspects of foreign exchange management and valuation issues play a crucial role in papers on finance with an international focus. Against this background, we will take a closer look at the contents of a selection of important textbooks on international financial management in Sect. 3. Section 4 presents this special issue's four papers, and Sect. 5 concludes.

\section{International finance at the annual meetings of the European Finance Association}

Just to get an idea of the importance of the international dimension in the field of finance, we have taken a look at the annual meetings of the EFA from 2009 to 2020. Along with the annual meetings of the Western Finance Association and the American Finance Association, the EFA conferences are some of the most prestigious 
worldwide. On average, around 232 papers are presented at each annual meeting, of which around $5.78 \%$ have a pronounced international focus as highlighted by the term "international" in their title, their key words, or their session heading. This does not rule out the possibility of an international "flavor" in some of the other papers. Nevertheless, in such cases, this typically will not be the main focus of the respective study. Rather interestingly, this percentage of papers as identified according to our criteria as "internationally related" was somewhat higher from 2009 to 2014 (6.8\%) than from 2015 to 2021 (4.8\%). However, these figures are generally quite stable over time. The number of downloads of these contributions that are available at the Social Science Research Network is almost the same. This means that papers with an international focus are of rather "average" interest for the scientific community.

We started with a co-occurrences analysis of paper titles, highlighting which words commonly occur together. Figure 1 documents the results for the entire timespan from 2009 to 2020 as well as for the two subperiods 2009-2014 and 2015-2020. It shows that, in addition to the relatively isolated field of monetary policy, most paper titles seem to center around topics related to foreign exchange, currency, market risk, and asset prices.

In order to gain additional insights, we applied the state-of-the-art machine learning method "Latent Dirichlet Allocation" (LDA) (Blei et al. 2003) to the abstracts of the EFA conference papers separately for the papers presented from 2009 to 2014 and those presented from 2015 to 2020. The LDA is an advanced textual analysis technique that views each abstract as a union of topics and each topic as a union of words. This approach mimics human language processing, as it classifies documents into natural groups without any pre-specified topics. The LDA applies mathematics to reduce the dimensionality of datasets and thus is similar to a factor analysis (Dyer et al. 2017). This reduction is achieved by defining a topic as a collection of words where each word is assigned a probability of belonging to a topic. Thus, the LDA connects documents with probability distributions belonging to topics, so that one document can contain several topics. We restricted our analysis to identifying the five main topics for both subperiods.

The results are shown in Fig. 2, which lists relevant topics and their most important words. One problem is that we have to determine a suitable heading for each topic "manually", as this cannot be generated automatically. Our suggestions are also presented in Fig. 2. For each topic of our two subsamples, Fig. 3 presents the probability $\gamma$ that a given abstract deals with a given topic. For most topics, it is an either-or decision whether a paper is assigned to this topic, since probabilities are usually close to 0 or 1 .

If we restrict our examination to those papers which can be assigned to one topic with a probability of at least $80 \%$, we get the following frequency distribution for 2009-2014: asset pricing (11.11\%), currency risk models (13.33\%), global portfolio management $(21.11 \%)$, investment management $(22.22 \%)$, and U.S. banking crisis (20\%). Of the 89 papers, $12.22 \%$ could not be assigned to one of these five categories with sufficient precision. The corresponding results for 2015-2020 are: asset pricing (23.19\%), bank risk taking (17.39\%), corporate debt financing $(15.94 \%)$, currency risk models $(17.39 \%$ ), and mergers and acquisitions (17.39\%). For $8.70 \%$ of the 69 papers, it was not possible to determine just one dominant topic with sufficient precision. 


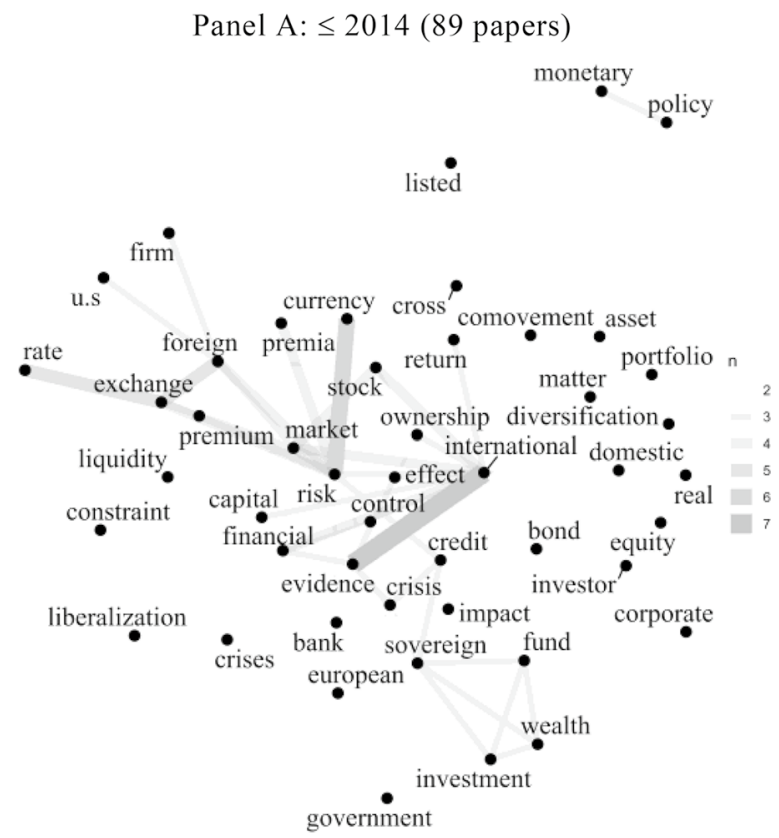

Panel B: $\geq 2015$ (69 papers)

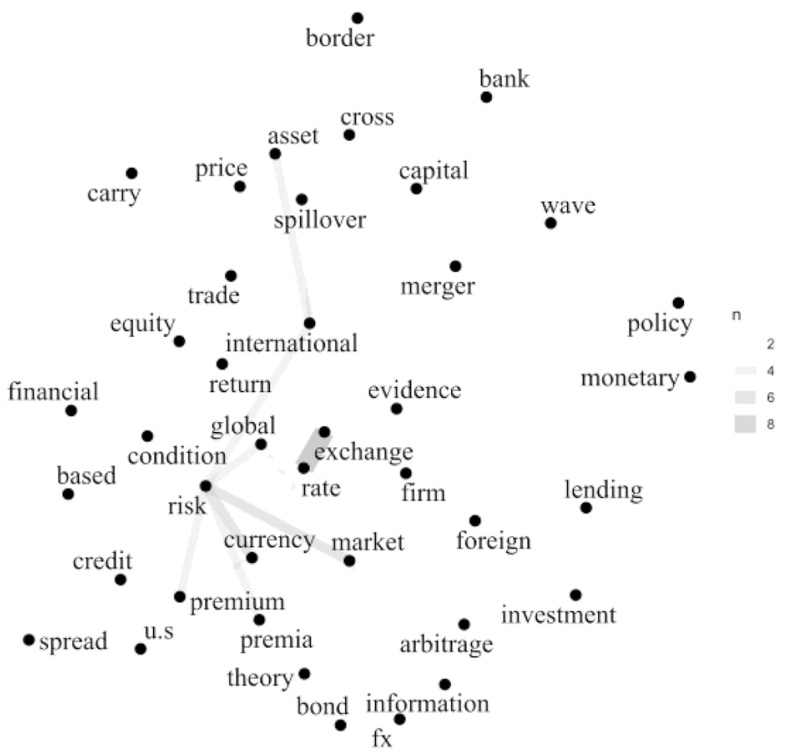

Fig. 1 Bi-grams of EFA conference papers on international finance. This figure shows the most common word pairs in working paper titles presented at EFA conferences between 2009 and 2014 as well as between 2015 and 2020. The number $\mathrm{n}$ of co-occurrences is indicated by the thickness of the connection lines; the most common words are located in the center 
As financing and investment decisions are also closely related to valuation and risk issues, we will rely primarily on these aspects for our analysis of textbooks in the next section.

\section{Insights from recent textbooks on international financial management}

While it is impossible to present all of the developments in international financial management made in the last four decades, the fruits of this theoretical and empirical research can be found in numerous textbooks and handbooks that cover investment and financing decisions in an international context.

We conducted a literature review on current textbooks and handbooks on international financial management. In order to reflect an up-to-date perspective of current knowledge on international financial management, we have restricted our review to books published in the last 20 years that we are aware of. ${ }^{2}$ To keep the assessment manageable, books on international macroeconomics, international business or international management have been excluded. Of course, the resulting sample of literature is selective and incomplete. ${ }^{3}$ Nevertheless, in our opinion, the resulting sample of 14 textbooks reflects the current state of basic knowledge on international financial management that academics deem necessary to convey to future researchers and practitioners (see also Boland 1997, pp. 109-110).

Our, admittedly rather limited, literature review aims to answer the following key methodologically driven questions on international finance: (1) What theoretical framework is presented for exchange rate determination and forecasting? (2) What exchange rate forecasting method is applied when presenting valuation examples? (3) What valuation methods do textbooks propose for conducting cross-border valuations? (4) What method is proposed to calculate the cost of equity? (5) How do the textbooks evaluate the hypothesis that the home currency and foreign currency approaches are equivalent? ${ }^{4}$ We acknowledge that these five questions are not at all comprehensive, and that other interesting questions have not been considered.

\footnotetext{
${ }^{2}$ We focused the literature review on publications in English, and did not include general textbooks on corporate finance or financial management. Please note that many such textbooks contain one or more chapters on international financial management issues; see for example standard textbooks such as Berk and DeMarzo (2020, pp. 1097-1112), Brealey et al. (2020, pp. 717-736), Brigham and Daves (2010, pp. 1016-105), Copeland et al. (2014, pp. 785-830), Moles et al. (2011, pp. 837-886) and Ross et al. (2020, pp. 935-957). Valuation handbooks and textbooks such as Koller et al. (2020) or Holthausen and Zmijewski (2020), and textbooks on global investments such as Solnik and McLeavey (2014) were likewise not included. These books basically reflect the same methodological approach as the textbooks presented in our review that specialize in international financial management. Therefore, not including such handbooks and textbooks has no material effect on our conclusions.

3 We apologize if valuable textbooks and handbooks we are not aware of have not been included in our literature review on international financial management.

4 According to the home currency approach, the market value of future payoffs in foreign currencies has to be converted into the home currency with the respective expected future exchange rate. This future payoff, now denominated in the home currency, is then discounted using the cost of capital of the home
} 


\section{Panel A: $\leq 2014$}

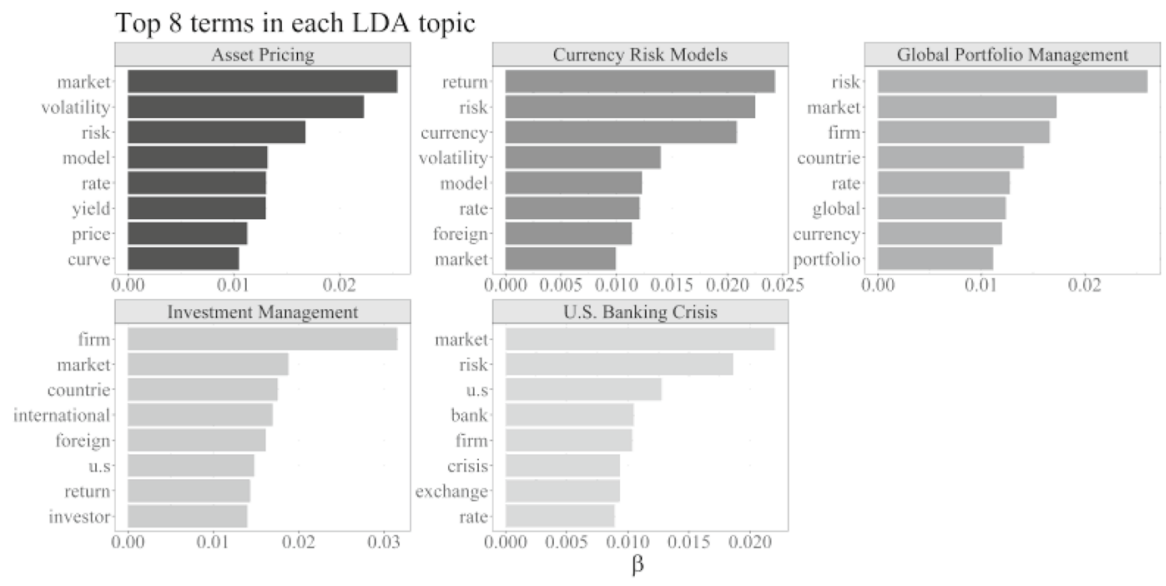

\section{Panel B: $\geq 2015$}

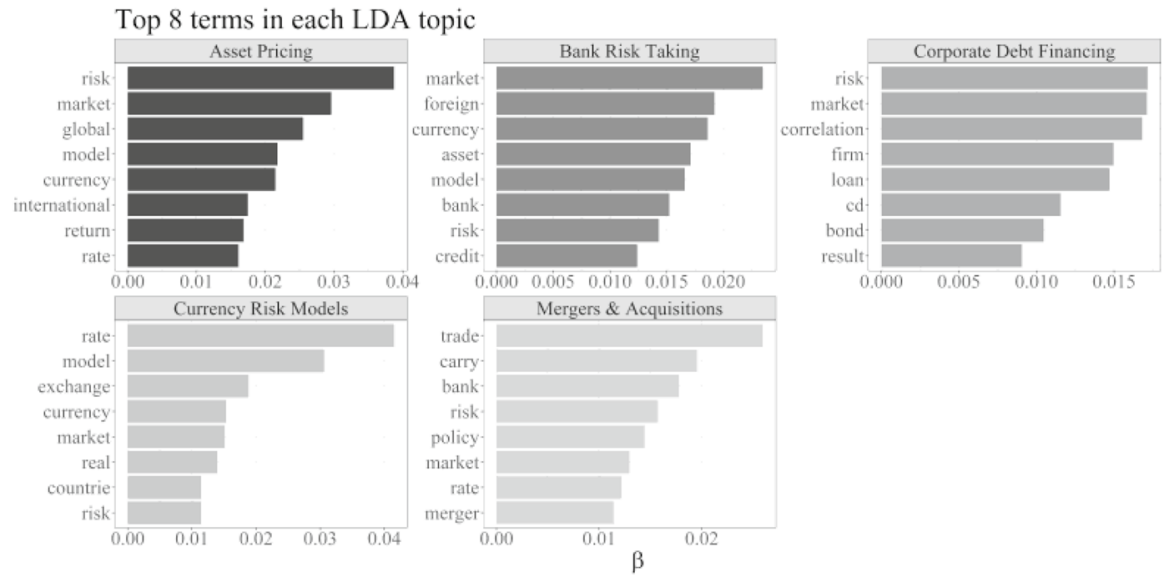

Fig. 2 LDA analysis of EFA conference papers on international finance. This figure shows the top 8 words for each of the 5 topics found by the LDA (Latent Dirichlet Allocation) in the abstracts of all papers from 2009 to 2014 (Panel A) as well as from 2015 to 2020 (Panel B) presented at the EFA conferences. Each word is connected with a probability $\beta$ of that word belonging to that topic

However, we believe that the questions addressed in our review are highly relevant in a vast majority of practical and empirical cases.

\section{Footnote 4 (continued)}

currency to obtain a market value expressed in the home currency. Instead, the foreign currency approach discounts future payoffs in foreign currencies with the foreign currency's cost of capital. The resulting net present value is then converted to the home currency using the spot rate. Both approaches are deemed to be equivalent under certain conditions. 
Panel A: $\leq 2014$

Distribution of probability for each topic

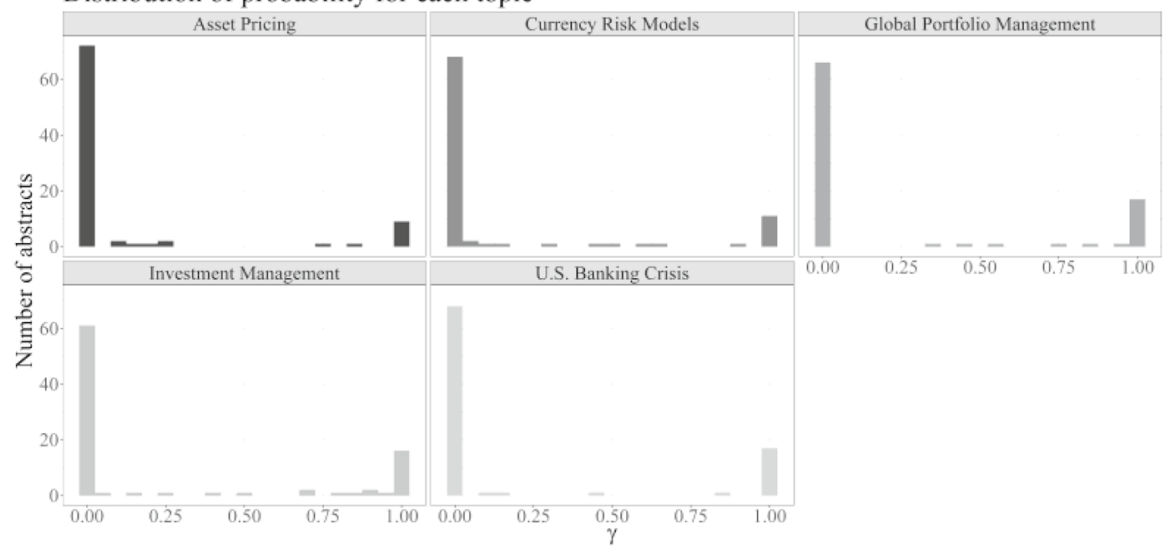

Panel B: $\geq 2015$

Distribution of probability for each topic

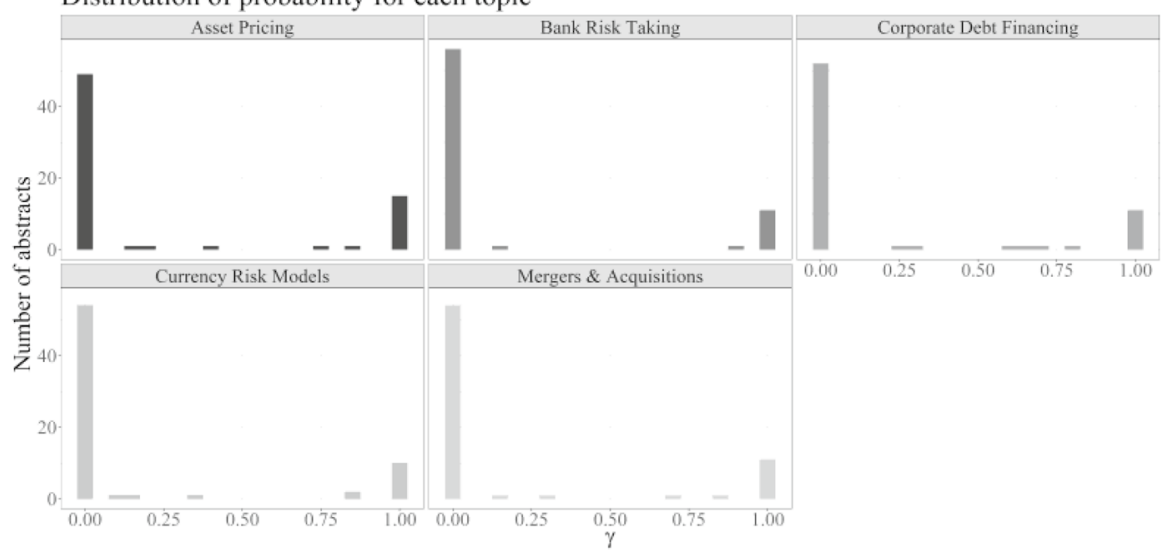

Fig. 3 Probability of an abstract belonging to a topic. This figure shows the probability $\gamma$ that an abstract from the EFA conference papers belongs to a specific topic. The y-axis counts the number of abstracts and is $\log (10)$ scaled. Results in Panel $\mathbf{A}$ are based on all papers presented at the EFA conferences between 2009 and 2014, while Panel B analyzes papers from 2015 to 2020

Table 1 presents the results of our limited literature review on the first two questions regarding the methodology used to forecast future exchange rates.

The sample of currently available textbooks presented in Table 1 emphasizes the relevance of exchange rate determination and forecasting and uses international 
parity relations (IPR) as the relevant theoretical framework. ${ }^{5}$ In contrast, textbooks on international financial management available shortly before and after the breakdown of the Bretton Woods regime did not cover this area. ${ }^{6}$ With a free-float regime, it became more and more necessary to forecast exchange rates (see Giddy and Dufey 1975). ${ }^{7}$ An early coherent presentation of international parity conditions as an integrated theory of exchange rate equilibrium based on expectations can be found in Giddy (1976), Aliber (1978), and Roll and Solnik (1979). This framework still underpins the theoretical exposition of the current textbooks presented in Table 1. Our sample confirms that the theoretical foundation of exchange rate determination and forecasting based on international parity conditions has remained the relevant paradigm since the breakdown of the Bretton Woods system of fixed rates.

In line with the efficient market hypothesis (EMH), Giddy (1976), p. 883, concluded some years after the breakdown of the Bretton Woods system that interest differentials and forward rates provide "the best forecast of the future spot rate", respectively. ${ }^{8}$ In current textbooks, the prevalent forecasting method still appears to be the market-based approach, i.e. using forward rates as a direct predictor of future exchange rates when assuming risk neutrality or as the certainty equivalent of future exchange rates when assuming risk aversion. In the latter case some textbooks indicate that, due to small risk-premium estimates, the risk aversion case and the risk neutrality case deliver similar forecasts. However, several textbooks refer to their own or third-party empirical work in the last decades, indicating weaknesses and exchange rate anomalies in contradiction to economic theory. These affect not only the uncovered interest rate parity ("forward premium puzzle"; for a comprehensive review see Miller 2014), but other parity conditions as well (for the purchasing power parity (PPP) puzzle, see Rogoff 1996). These and other anomalies still challenge economic theory on exchange rate determination and forecasting (e.g. Obstfeld and Rogoff 2000). The volatility of exchange rates and these empirical findings make it clear that no forecasting method can promise ex ante forecasting infallibility (Rossi 2013). Research reported in these textbooks also shows that, where profitable

\footnotetext{
${ }^{5}$ Please note that in the textbooks under review the term for "forward rate expectations parity" varies significantly from textbook to textbook, where it is also called "unbiasedness hypothesis", "forward parity", "forward rate unbiasedness" or "forward unbiasedness hypothesis", etc. The uncovered interest rate parity (UIP) is sometimes also called "Fisher open".

${ }^{6}$ For example, Zenoff and Zwick (1969), a textbook written during the Bretton Woods regime of fixed exchange rates, reduces the exchange rate forecasting problem to the forecasting of inflation as a primary cause of currency devaluations and the imposition of exchange controls. The textbook by Weston and Sorge (1972), which was written shortly after the breakdown of the Bretton Woods system, likewise does not discuss international parity conditions and their possible applicability to forecasting.

7 The textbook Rodriguez and Carter (1984), the third edition of which was written in the mid-1980s, already had a clear focus on exchange rate determination and forecasting and used the concept of efficient markets and prediction based on forward exchange rates, see pp. 114-146; see also Abdullah (1987), pp. 54-55. The textbook by Evans (1992) presents also the efficient markets version of the relative purchasing power parity connecting both theories, see Roll (1979), Shapiro (1983) and, Adler and Lehmann (1983).

${ }^{8}$ Levich (1979b), pp. 258-259, presents an early account of studies on the forecasting accuracy of the forward rate conducted after the breakdown of the Bretton Wood system; see also Levich (1978, 1979a, 1980, 1983, 1984).
} 


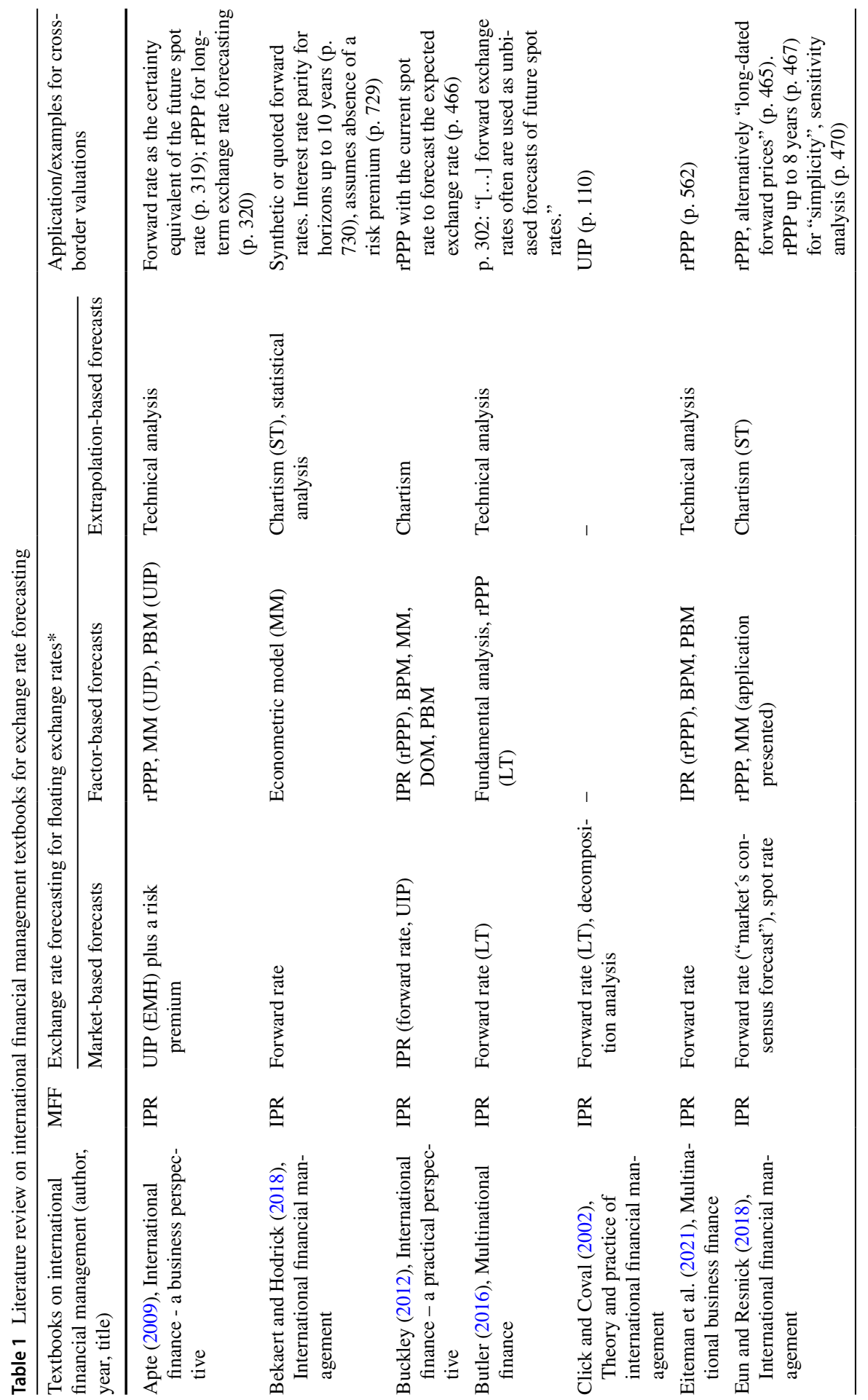




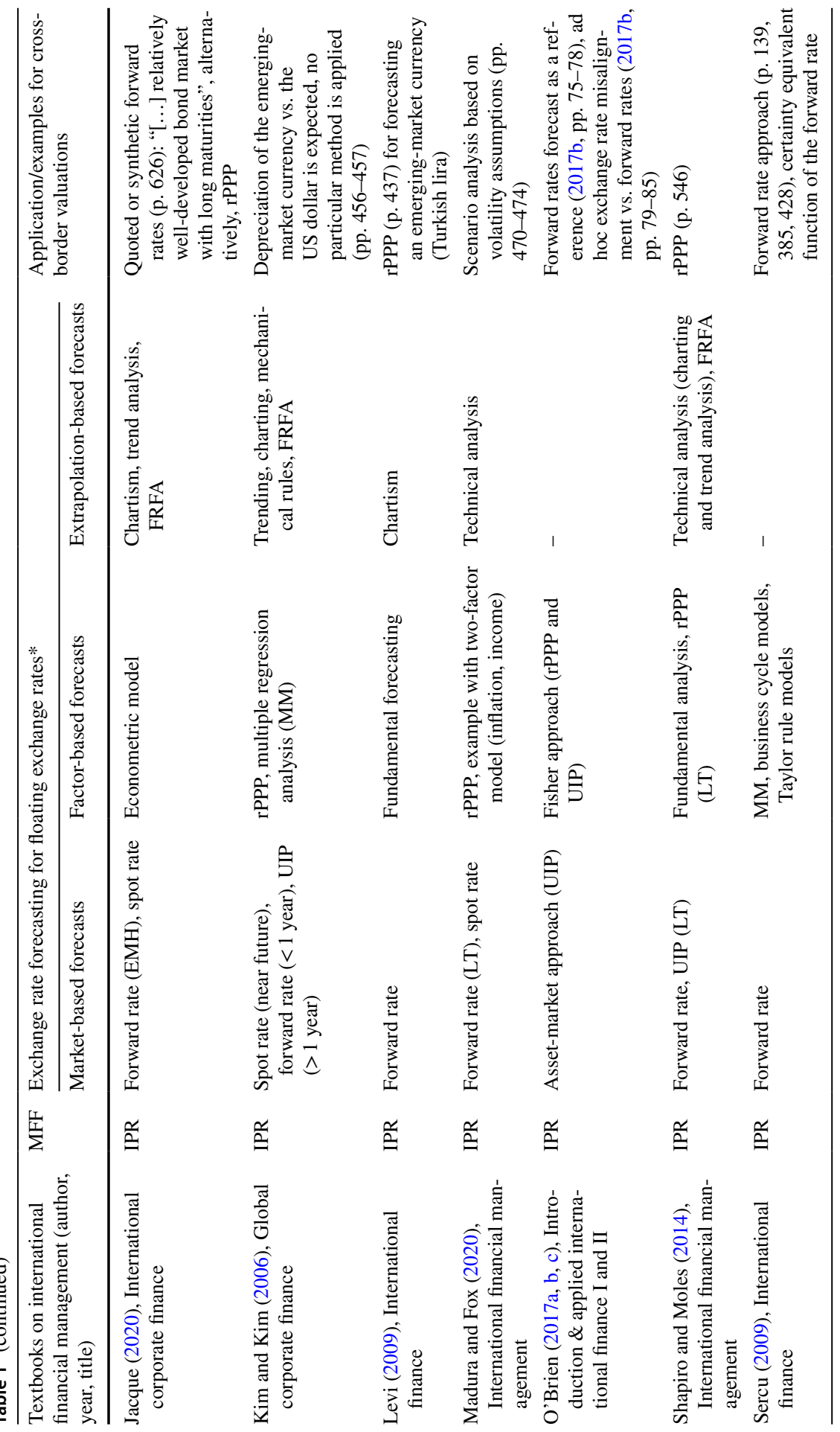




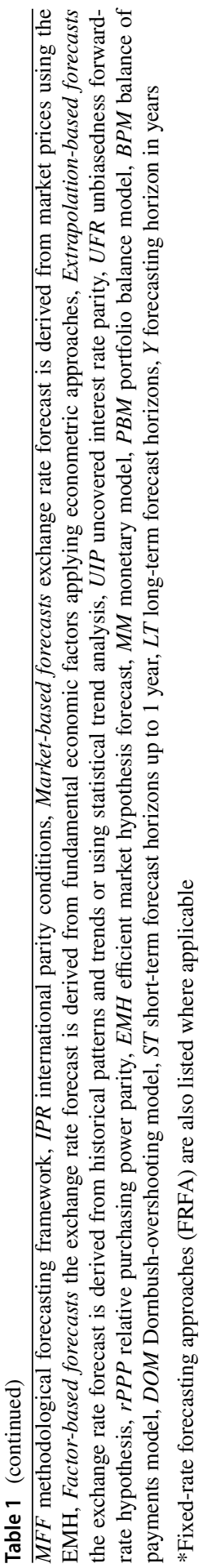


trading strategies taking advantage of these anomalies are discovered, the anomalies tend to disappear once transaction costs and risks are considered.

Shapiro and Moles (2014) point out that exchange rate forecasting is to be viewed in relative terms and that any alternative currency forecasting model should be required to outperform "the market's estimates of currency changes" (p. 169). This is still a "daunting task" (Fama 1998, p. 284). While alternative approaches to UIP or relative PPP are presented in the textbook literature we reviewed (see Table 1), the textbooks do not claim that these alternative approaches can consistently "beat the market". As Jacque (2020), p. 470, puts it: The "lack of a definitive answer to the general question of forecasting exchange rates, [...], is probably one of the most potent justifications for undertaking costly and at times highly constraining hedging policies against foreign exchange risk." Thus, exchange rate risk is intertwined not only with exchange rate forecasting, but also with hedging decisions based on it. As a consequence, the distinction between fallacious and valid reasons to hedge (e.g. Levi and Sercu 1991) and a proper measurement of currency risk (Adler and Dumas 1984; O'Brien 2019) is key for sound exchange rate risk management.

Interestingly, in the textbooks we reviewed, it appears that only Sercu (2009) and Apte (2009) emphasize the role of the forward rate as a certainty equivalent of the future exchange rate. Based on this, Sercu (2009) proposes using the forward rate as a guide for commercial and financing decisions (p. 193), as well as for accounting purposes (pp. 190-192). While his proposal of using the forward rate instead of the spot rate in accounting is probably at odds with most accounting standards, this approach treats the decision not to hedge in the same way as the decision to hedge and provides an economically sound division of profits into operating income and financial income. It remains to be seen if his proposal is picked up by standard setters.

Most textbooks briefly present technical analysis and fundamental analysis as additional exchange rate determination and forecasting approaches. Fundamental analysis aims to identify causality relationships that determine the current spot rate based on economic factors. As Eun and Resnick (2018), pp. 160-161, show, based on a monetary approach, in order to produce a forecast for an exchange rate with a fundamental method, the values to be estimated are not the current values, but the future values of the independent variables. This substantially exacerbates the exchange rate forecasting problem for practical applications due to expanding data requirements in order to estimate an array of variables to formulate a forecast. The rather frequent, albeit usually brief, inclusion of technical analysis, a practitioners' tool that defies economic fundamentals and the market efficiency concept, is somewhat surprising and probably can only be explained by its relevance to short-term forecasting for many foreign exchange professionals (see Menkhoff and Taylor 2007, for a comprehensive review). ${ }^{9}$

\footnotetext{
9 The textbooks reviewed usually do not recommend technical analysis and fundamental analysis for practical applications. Technical analysis is deemed to be suitable, if at all, for short forecast horizons, see Eiteman et al. (2021), p. 285. Most textbooks state that technical analysis is only able to indicate the direction of exchange rate changes and is therefore not suitable for period-specific forecasting.
} 
Table 2 presents the results of our limited literature review on the third to fifth questions in international finance and shows that there is a clear preference for the adjusted present value (APV) method developed by Myers (1974) over the weighted average cost of capital (WACC) or the flow-to-equity (FTE) approaches. The latter method is only mentioned occasionally. This preference for using the APV approach in an international valuation setting can be traced back to Lessard (1985). The reasoning is that an international context must reflect different value components of financing side effects (e.g., different currencies, taxes, and subsidies). It is surprising that, in standard textbooks, the advantages of the APV approach (assuming predetermined debt levels) are not highlighted correspondingly, since these advantages do not apply exclusively in an international context. ${ }^{10}$ Most of the textbooks deem it necessary to consider an additional value component resulting from real options that may stem from a capital budgeting problem in an international context, while the difficulties of applying this concept in practice are usually not discussed (e.g. Kruschwitz and Lorenz 2020, pp. 362-401).

The equivalence of the home currency and foreign currency approaches is only addressed in some of the textbooks, while applying different sets of assumptions. Apte (2009), Bekaert and Hodrick (2018), Buckley (2012), Butler (2016), Click and Coval (2002), Levi (2009) and O'Brien (2017b) show under what conditions the equivalence holds and how differences may indicate the incurrence of a speculative financial position that should not be confused with an operative investment decision.

To estimate the cost of equity, nearly all textbooks advocate the use of the capital asset pricing model (CAPM) in an international context. ${ }^{11}$ To capture the international context in integrated capital markets, the use of the global CAPM is preferred to the more complex version, the international CAPM with additional currency risk factors. ${ }^{12}$ Some textbooks, such as Sercu (2009), O'Brien (2017b) and Bekaert and Hodrick (2018) present the international CAPM that incorporates exchange risk as a separate risk factor in addition to the market risk factor of the global CAPM. ${ }^{13}$ Only Jacque (2020) adds a separate ad hoc country risk factor in the global CAPM. ${ }^{14}$ Other textbooks propose capturing country risk with a scenario analysis at the

\footnotetext{
$\overline{10}$ See for example Drukarczyk and Schüler (2016, pp. 171), Holthausen and Zmijewski (2020, p. 16), and Koller et al. (2020, p. 178). For highly leveraged firms, see Arzac (1996), and for valuations with changing predetermined debt levels (probably the most common case in practice), see for example also Arzac (2008, pp. 96-102).

11 In contrast, Kim and Kim (2006) show no distinguishable preference among the CAPM, a dividend growth rate model and a price-to-earnings ratio model.

12 The term "global CAPM" is not used uniformly in the textbooks we reviewed; sometimes it is called "world CAPM" or even "international CAPM". Since the global CAPM assumes integrated capital markets, and not all capital markets in the world are integrated, we prefer the adjective "global" to "world". We reserve the term "international CAPM" for versions that consider exchange risk as an additional factor, while the global CAPM is a single-factor model.

13 Sercu (2009) presents a detailed derivation of the model and its conceptual implications; see also O'Brien (2017b) who provides an extensive demonstration of its application.

14 Jacque (2020) presents the approach of Damodaran (2003) without discussing the lack of conceptual consistency of this risk factor with the global CAPM, see for example Kruschwitz et al. (2012).
} 


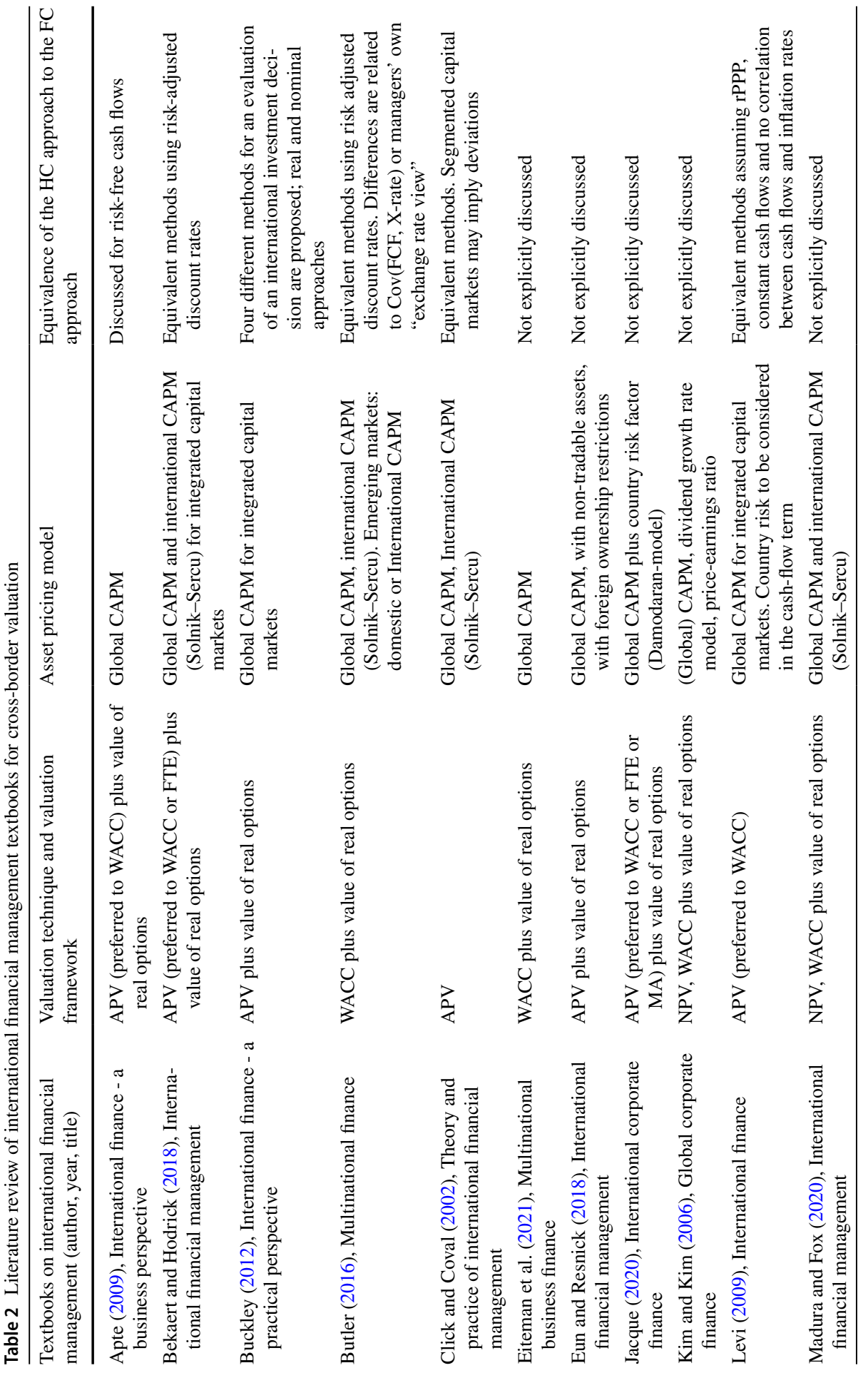




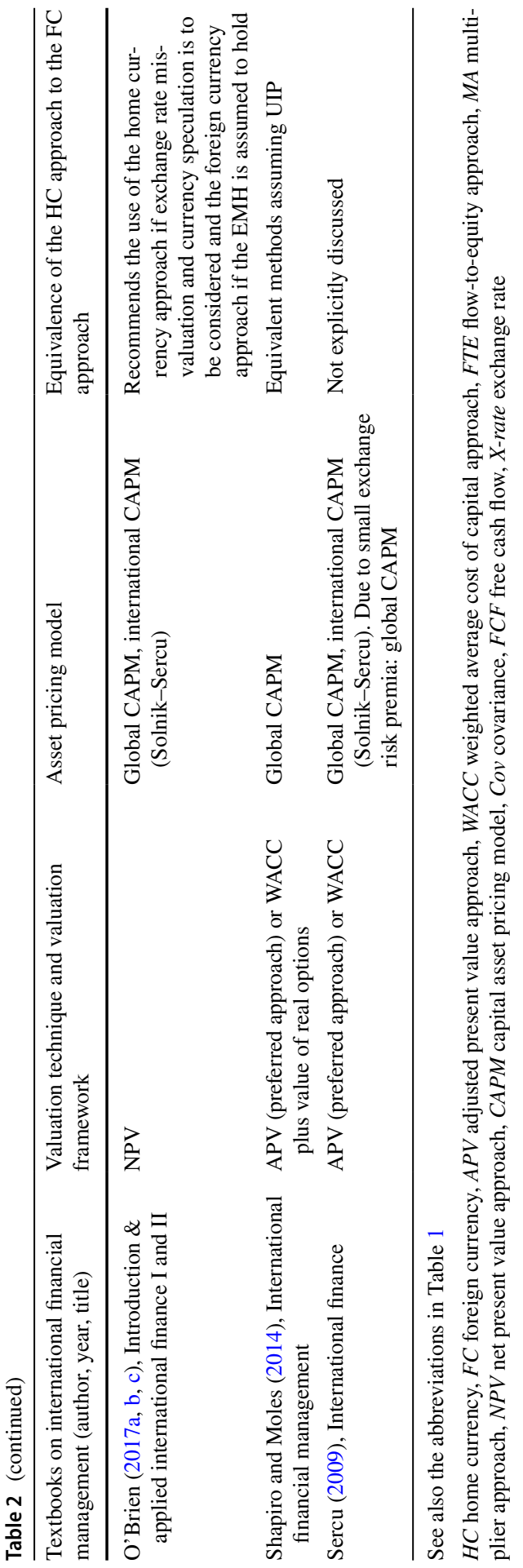


cash-flow level (e.g. Levi 2009, p. 435). Market-segmentation effects on the cost of equity consistent with the CAPM are only treated occasionally. Eun and Resnick (2018) propose an approach that extends the (global) CAPM to incorporate nontradable assets (see Alexander et al. 1987) and foreign ownership restrictions (see Eun and Janakiramanan 1986). Other models that capture relevant aspects of partially segmented capital markets consistent with the CAPM, such as Black (1974), Stulz (1981b), Errunza and Losq (1985), Merton (1987), and Bekaert and Harvey (1995), are not presented in the textbooks we reviewed.

Comparing the 12 models to calculate the international cost of capital that are brought forward in Harvey (2005) to the models presented in the textbooks, Table 2 shows a clear preference for Model 1 (global CAPM) for valuation in developed countries with sufficiently integrated capital markets; this confirms the recommendation in Harvey (2005). The remaining 11 models, most of which are not consistent with the CAPM, are not found in the textbook literature. ${ }^{15}$ For valuations in emerging markets, the degree of segmentation plays a major role when choosing an adequate model to estimate the cost of equity. In this respect, Harvey (2005) stresses that a term structure of country risk should be considered in long-term project evaluation, as segmentation may fade out. Summing up, for the assumption of partially segmented capital markets, no conclusive recommendation for a specific cost-ofequity model can be extracted from our limited review.

\section{The contributions in this special issue}

The literature review of textbooks in international financial management sheds some light on where we stand today and what knowledge is thought to be of use to future professionals and academics. It shows that theoretical and empirical research has found its way to the applied side of international finance. We can now put forward further interesting advances in international financial management included in this special issue of the Journal of Business Economics.

Schüler (2021) develops a comprehensive framework for cross-border discounted cash-flow valuation that is not found in the literature. The valuation framework encompasses the derivation of the risk-adjusted rate of return in order to discount future expected cash flow in accordance with the global CAPM while considering relevant risks such as exchange rate risk, business risk, financial risk, the risk related to tax shields, and the risk of default. The paper shows how the foreign currency and home currency approaches are equivalent when assuming uncertainty and risk aversion. This is demonstrated using the adjusted present value (APV) approach. The risk-adjusted discount rates to be used in the corresponding flow-to-equity (FTE) approach and in the weighted average cost of capital (WACC) approach are also presented. This paper is therefore relevant to the valuation of not only a foreign

15 The only exception is Model 7 that corresponds to the (ad hoc) country-risk model of Damodaran (2003). 
company, but also of a domestic company that generates cash flows in a foreign currency and/or uses debt-financing instruments denominated in a foreign currency.

In the article by Bartram et al. (2021), the literature on cross-sectional stockreturn predictability, with over 450 factors documented for different asset classes, is reviewed. Taking the perspective of an institutional investor, the authors guide the reader through this "zoo of factors", as they call it, discussing the evidence of factors and their relevance for an institutional investor. Their approach requires a theoretical rationale in order to identify the relevant "true" factors and differentiate them from factors resulting from data mining. According to their review, the performance of many factors depends on the inclusion of small- and micro-cap stocks. However, such securities are usually not relevant from an institutional investor's perspective, as an investment in these collides with liquidity requirements and involves higher transaction costs. Most factors have been detected in the U.S. equity markets and then reproduced in international markets. In particular, style factors such as value and momentum, but also other predictors appear in several international markets facilitating global factor-based investment strategies. The article presents a set of factors in equities and other asset classes, including currencies, fixed income and commodities, that the authors see as meaningful "ingredients" of factor-based portfolio construction. They also bring forward some key metrics, like the maximum Sharpe ratio and others, that may help to identify the better model. Nonetheless they advert that the choice of test and comparison techniques may drive the results and point out that discerning between risk, mispricing and statistical bias remains a challenge for researchers and investors.

Hammer et al. (2021), use a dataset of 1149 global private equity transactions to analyze cross-border buyouts. They find that significantly higher valuation multiples are observed for these transactions than for domestic ones. They attribute their finding to informational asymmetries with which foreign acquirers are confronted. They show how the valuation spread encountered there diminishes under circumstances where the information asymmetries decrease (e.g. accounting standards, public listing, local partnering, size of the acquirer and its organizational resources).

While Hammer, Janssen, and Schwetzler analyze the valuation effect of information asymmetries in private equity transactions, the study by Bobenhausen and Salzmann (2021) examines informational asymmetries and their valuation impact in public equity offerings. Bobenhausen and Salzmann expand previous studies on equity rights offerings and the effects occurring when they are announced. The focus lies on the relationship between the discount of an equity rights offering and the announcement effect. They show that the relationship between a discount that signals the quality of the equity offering and the announcement effect found in previous studies is especially relevant in environments with a particularly low level of capital market transparency, i.e. high informational asymmetry. Their study estimates announcement effects across several countries while considering different transparency environments for equity rights offerings. 


\section{Conclusion}

Certainly, international financial management and valuation is a special discipline in the broader field of finance. According to our analysis of the annual meetings of the European Finance Association, such topics are of persistent relevance, especially with respect to issues of foreign exchange management and asset pricing.

Our limited review of the textbook literature on international financial management has shown that international parity conditions, in particular the uncovered interest rate parity, the unbiasedness forward-rate hypothesis and the efficient markets version of the relative purchasing power parity continue to be the prevalent paradigms since the breakdown of the Bretton Woods system 50 years ago. An enormous amount of empirical research has shown that no exchange rate forecasting method is infallible and that some empirical anomalies still challenge economic theory, at least for some forecasting horizons, exchange rates and periods. However, empirical research also indicates that no pervasive trading strategies to "beat the market" can be devised after considering transaction costs and risk. The assumption of sufficient market integration appears to be the prevalent assumption in most textbooks on international financial management. Cross-border valuation of businesses or projects in less developed countries, where a high degree of segmentation must be considered, remains both a theoretical and practical challenge.

In a similar way, the topics presented in this special issue on international financial management show clearly that this is an area of ongoing research with high demand for practical applications. Schüler presents a comprehensive model for cross-border valuation, while Bartram, Lohre, Poe, and Ranganathan deliver a tour de force through the empirical research on relevant investment factors for different asset classes across the globe from the perspective of an institutional investor. Hammer, Janssen, and Schwetzler as well as Bobenhausen and Salzmann show how information asymmetries in cross-border situations influence the value of the investment target in private transactions or in public offerings. All these contributions give valuable theoretical and empirical insights for investment and financing decisions that management or investors need to consider in an international context. It shows that fruitful developments relating to academic research and its practical application are and will remain a key feature of this field of financial economics.

Funding Open Access funding enabled and organized by Projekt DEAL.

Open Access This article is licensed under a Creative Commons Attribution 4.0 International License, which permits use, sharing, adaptation, distribution and reproduction in any medium or format, as long as you give appropriate credit to the original author(s) and the source, provide a link to the Creative Commons licence, and indicate if changes were made. The images or other third party material in this article are included in the article's Creative Commons licence, unless indicated otherwise in a credit line to the material. If material is not included in the article's Creative Commons licence and your intended use is not permitted by statutory regulation or exceeds the permitted use, you will need to obtain permission directly from the copyright holder. To view a copy of this licence, visit http://creativecommons.org/licen ses/by/4.0/. 


\section{References}

Abdullah FA (1987) Financial management for the multinational firm. Prentice Hall, Englewood Cliffs

Adler M, Dumas B (1983) International portfolio choice and corporation finance: a synthesis. J Financ 38:925-984

Adler M, Dumas B (1984) Exposure to currency risk: definition and measurement. Financ Manag 13:41-50

Adler M, Lehmann B (1983) Deviations from purchasing power parity in the long run. J Financ 38:1471-1487

Alexander GJ, Eun CS, Janakiramanan S (1987) Asset pricing and dual listing on foreign capital markets: a note. J Financ 42:151-158. https://doi.org/10.2307/2328425

Aliber RZ (1978) Exchange risk and corporate international finance, reprint, 1980th edn. The MacMillan Press Ltd, London

Apte PG (2009) International finance - a business perspective, 2nd edn. McGraw Hill, New Delhi

Arzac ER (1996) Valuation of highly leveraged firms. Financ Anal J 52:42-50. https://doi.org/10.2469/ faj.v52.n4.2010

Arzac ER (2008) Valuation for mergers, buyouts, and restructuring, 2nd edn. John Wiley \& Sons, Hoboken

Baldwin R, Wyplosz C (2020) The economics of European integration, 6th edn. Irwin/McGraw-Hill, Maidenhead

Bank for International Settlements (1996) Central Bank Survey of foreign exchange and derivatives market activity 1995 report

Bank for International Settlements (2019) Triennial Central Bank Survey, December 2019, global foreign exchange market turnover in 2019 report

Bartram SM, Lohre H, Pope PF, Ranganathan A (2021) Navigating the factor zoo around the world: an institutional investor perspective. J Bus Econ. https://doi.org/10.1007/s11573-021-01035-y

Bekaert G, Harvey CR (1995) Time-varying world market integration. J Financ 50:403-444. https://doi. org/10.1111/j.1540-6261.1995.tb04790.x

Bekaert G, Hodrick RJ (2018) International financial management, 3rd edn. Cambridge University Press, Cambridge

Berk J, DeMarzo P (2020) Corporate finance, 5th edn. Pearson, Harlow

Black F (1974) International capital market equilibrium with investment barriers. J Financ Econ $1: 337-352$

Blei DM, Ng AY, Jordan MI (2003) Latent Dirichlet allocation. J Mach Learn Res 3:993-1022

Bobenhausen N-C, Salzmann AJ (2021) Discount, transparency and announcements effects of equity rights offerings: international evidence. J Bus Econ. https://doi.org/10.1007/s11573-020-01023-8

Boland L (1997) Critical economic methodology: a personal odyssey. Routledge, London

Brasche U (2013) Europäische integration, 3rd edn. Oldenbourg Verlag, Munich

Brealey RA, Myers SC, Allen F (2020) Principles of corporate finance, 13th edn. McGraw-Hill Education, New York

Brigham EF, Daves PR (2010) Intermediate financial management, 11th edn. Cengage Learning, Mason Buckley A (2012) International finance. Pearson Education Limited, Harlow

Butler KC (2016) Multinational finance, 6th edn. John Wiley \& Sons Inc, Hoboken

Click RW, Coval J (2002) The theory and practice of international financial management. Prentice-Hall, Upper Saddle River

Copeland TE, Weston JF, Shastri K (2014) Financial theory and corporate policy, new international edition, 4th edn. Pearson Education Limited, Harlow

Damodaran A (2003) Country risk and company exposure: theory and practice. J Appl Financ 13(4):63-76

Das DK (2004) Financial globalization and the emerging market economies. Routledge, New York

Das DK (2006) Globalization in the world of finance: an analytical history. Glob Econ J 6:1850081

Drukarczyk J, Schüler A (2016) Unternehmensbewertung, 7th edn. Verlag Franz Vahlen GmbH, Munich

Dyer T, Lang M, Stice-Lawrence L (2017) The evolution of 10-K textual disclosure: evidence from latent Dirichlet allocation. J Acc Econ 64:221-245. https://doi.org/10.1016/j.jacceco.2017.07.002

Eiteman DK, Stonehill AI, Moffett MH (2021) Fundamentals of multinational finance, global edition, 6th edn. Pearson, Boston 
Errunza V, Losq E (1985) International asset pricing under mild segmentation: theory and test. J Financ 40:105-124

Eun CS, Janakiramanan S (1986) A model of international asset pricing with a constraint on the foreign equity ownership. J Financ 41:897-914

Eun CS, Resnick BG (2018) International financial management, 8th edn. McGraw-Hill Education, New York

Evans JS (1992) International finance: a markets approach. Dryden Press

Fama EF (1998) Market efficiency, long-term returns, and behavioral finance. J Financ Econ 49:283-306

Franke G (1981) Theorie internationaler kapitalmärkte. Z Betriebswirt 51:51-66

Franke G, Hax H (2009) Finanzwirtschaft des Unternehmens und Kapitalmarkt, 6th edn. Springer-Verlag, Berlin

Frieden JA (2020) Global capitalism: its fall and rise in the twentieth century, and its stumbles in the twenty-first. W. W. Norton \& Company, New York

Giddy IH (1976) An integrated theory of exchange rate equilibrium. J Financ Quant Anal 11:883-892. https://doi.org/10.2307/2330587

Giddy IH, Dufey G (1975) The random behavior of flexible exchange rates: implications for forecasting. J Int Bus Stud 6:1-32

Grauer FL, Litzenberger RH, Stehle RE (1976) Sharing rules and equilibrium in an international capital market under uncertainty. J Financ Econ 3:233-256

Hammer B, Janssen N, Schwetzler B (2021) Cross-border buyout pricing. J Bus Econ. https://doi.org/10. 1007/s11573-020-01021-w

Harvey CR (2005) 12 Ways to calculate the international cost of capital. Duke University (Revised October 14, 2005), working paper

Holthausen RW, Zmijewski ME (2020) Corporate valuation: theory, evidence \& practice, 2nd edn. Cambridge Business Publishers, LLC, Cambridge

International Monetary Fund (IMF) (2020) Annual report on exchange arrangements and exchange restrictions 2019

Jacque LL (2020) International corporate finance, 2nd edn. John Wiley \& Sons, Hoboken

Kim SH, Kim SH (2006) Global corporate finance, 6th edn. Blackwell, Malden

Koller T, Goedhart M, Wessels D (2020) Valuation: measuring and managing the value of companies, 7th edn. Wiley, Hoboken

Kruschwitz L, Löffler A (2020) Stochastic discounted cash flow: a theory of the valuation of firms, 2nd edn. Springer Nature, Cham

Kruschwitz L, Lorenz D (2020) Investitionsrechnung, 15th edn. Oldenbourg Wissenschaftsverlag GmbH, Munich

Kruschwitz L, Löffler A, Mandl G (2012) Damodaran's country risk premium: a serious critique. Bus Valuat Rev 31:75-84

Lessard DR (1985) International financial management, 2nd edn. Wiley, New York

Levi MD (2009) International finance, 5th edn. Routledge, New York

Levi MD, Sercu P (1991) Erroneous and valid reasons for hedging foreign exchange rate exposure. J Multinatl Financ Manag 1:25-37

Levich RM (1978) Further results on the efficiency of markets for foreign exchange. In: Federal Reserve Bank of Boston (ed) Managed exchange rate flexibility: the recent experience. Federal Reserve Bank of Boston, pp 58-80

Levich RM (1979a) Are forward exchange rates unbiased predictors of future spot rates? Columbia J World Bus 14:49-61

Levich RM (1979b) On the efficiency of markets for foreign exchange. In: Dornbusch R, Frenkel JA (eds) International economic policy. The Johns Hopkins Univerty Press, Baltimore, pp 246-269

Levich RM (1980) Analyzing the accuracy of foreign exchange advisory services: theory and evidence. In: Levich RM, Wihlborg C (eds) Exchange risk and exposure: current developments in international financial management. Lexington Books, Lexington, pp 99-127

Levich RM (1983) Section 8.1: exchange rate forecasting techniques. In: George AM, Giddy IH (eds) International finance handbook, vol 2. John Wiley \& Sons, pp 1-30

Levich RM (1984) The efficiency of markets for foreign exchange: a review and extension. In: Gay GD, Kolb RW (eds) International finance: concepts and issues. RF Dame, pp 397-428

Madura J, Fox R (2020) International financial management, 5th edn. Cengage Learning Emea, London

Mehra R (1978) On the financing and investment decisions of multinational firms in the presence of exchange risk. J Financ Quant Anal 13:227-244 
Menkhoff L, Taylor MP (2007) The obstinate passion of foreign exchange professionals: technical analysis. J Econ Lit 45:936-972. https://doi.org/10.1257/jel.45.4.936

Merton RC (1987) A simple model of capital market equilibrium with incomplete information. J Financ 42:483-510

Miller NC (2014) Exchange rate economics: the uncovered interest parity puzzle and other anomalies. Edward Elgar Publishing, Cheltenham

Moles P, Parrino R, Kidwell DS (2011) Corporate finance. John Wiley \& Sons, Chichester

Myers SC (1974) Interactions of corporate financing and investment decisions - implications for capital budgeting. J Financ 29:1-25

O'Brien TJ (2017a) Applied international finance I: international cost of capital and capital budgeting, vol I, 2nd edn. Business Expert Press, New York

O'Brien TJ (2017b) Applied international finance II: managing foreign exchange risk, vol II, 2nd edn. Business Expert Press, New York

O'Brien TJ (2017c) Introduction to foreign exchange rates, 2nd edn. Business Expert Press, New York

O'Brien TJ (2019) Interactive trilateral foreign exchange exposure: insights from scenario analysis. Manag Financ 45:856-868. https://doi.org/10.1108/MF-11-2018-0566

Obstfeld M, Rogoff K (2000) The six major puzzles in international macroeconomics: is there a common cause? NBER Macroecon Annu 15:339-390

Obstfeld M, Taylor AM (2004) Global capital markets. Cambridge University Press, Cambridge

Rodriguez RM, Carter EE (1984) International financial management, 3rd edn. Prentice Hall, Englewood Cliffs

Rogoff K (1996) The purchasing power parity puzzle. J Econ Lit 34:647-668

Roll R (1979) Violations of purchasing power parity and their implications for efficient international commodity markets. In: Sarnat M, Szegö GP (eds) International finance and trade, vol I. Ballinder Publishing Company, Cambridge, pp 133-176

Roll R, Solnik B (1979) On some parity conditions encountered frequently in international economics. J Macroecon 1:267-283. https://doi.org/10.1016/0164-0704(79)90002-8

Ross SA (2004) Neoclassical finance. Princeton University Press, Princeton

Ross SA, Walsh MM (1983) A simple approach to the pricing of risky assets with uncertain exchange rates. In: Hawkins RG, Levich RM, Wihlborg CG (eds) Research in international business and finance, vol 3. JAI Press Inc., Greenwich, pp 39-54

Ross SA, Westerfield RW, Jaffe JF, Jordan BD (2020) Corporate finance, 12th edn. McGraw-Hill Education, New York

Rossi B (2013) Exchange rate predictability. J Econ Lit 51:1063-1119

Schüler A (2021) Cross-border DCF valuation: discounting cash flows in foreign currency. J Bus Econ. https://doi.org/10.1007/s11573-020-01013-w

Sercu P (1980) A generalisation of the international asset pricing model. Revue De L'association Française De Finance 1:91-135

Sercu P (2009) International finance: theory into practice. Princeton University Press, Princeton

Shapiro AC (1983) What does purchasing power parity mean? J Int Money Financ 2:295-318

Shapiro AC, Moles P (2014) International financial management. Wiley \& Sons Ltd, Chichester

Solnik BH (1974) An equilibrium model of the international capital market. J Econ Theory 8:500-524

Solnik BH, McLeavey DW (2014) Global investments, new international edition, 6th edn. Pearson Education Limited, Harlow

Stehle R (1981) Internationales finanzmanagement. Z Betriebswirt 51:67-77

Stulz RM (1981a) A model of international asset pricing. J Financ Econ 9:383-406

Stulz RM (1981b) On the effects of barriers to international investment. J Financ 36:923-934. https://doi. org/10.1111/j.1540-6261.1981.tb04893.x

United Nations (2021) UN operational rates of exchange. https://treasury.un.org/operationalrates

Wagener H-J, Eger T (2014) Europäische integration, 3rd edn. Vahlen, Munich

Weston VF, Sorge BW (1972) International managerial finance. Richard D. Irwin Inc., Homewood

Zenoff DB, Zwick J (1969) International financial management. Prentice-Hall, Englewood Cliffs

Publisher's Note Springer Nature remains neutral with regard to jurisdictional claims in published maps and institutional affiliations. 